\title{
Prezentacje
}

\section{Od pamięci do fikcji - analiza genetyczna}

Hans Walter Gabler

TEKSTY DRUGIE 2016, NR 6, S. 425-439

DOI: $10.18318 /$ td.2016.6.26 (i)

Tłumaczenie powstało W ramach grantu „Redefiniowanie filologii", nr 0031 / $\mathrm{NPRH}_{2} / \mathrm{H}_{11} / 81 / 2012$.

Źródło: H.W. Gabler From Memory to Fiction: An Essay in Genetic Criticism w: The Cambridge Companion to 'To the Lighthouse', ed. A. Pease, Cambridge 2014. Druk za zgodą Autora.

Hans Walter Gabler

(ur. 1938) - emerytowany profesor monachijskiego Ludwig-Maximilians Universität, doktor honoris causa National University of Ireland w Maynooth.

Znawca twórczości

J. Joycéa, twórca pionierskiej edycji Ulysses. A Critical and Synoptic Edition (Nowy Jork-Londyn 1984, t. 1-3), autor licznych publikacji poświęconych krytyce tekstu, badaniu procesu twórczego oraz edytorstwu cyfrowemu.

Dziennik 1915-1941, oprac. A.O. Bell, przeł. M. Heydel, Wydawnictwo Literackie, Kraków 2007. Skróty D2, D3 odsyłają do kolejnych tomów dzienników wydanych w języku angielskim, zaś cyfry w nawiasie kwadratowym do przekładu polskiego.

2 Monks House było wiejską rezydencją Leonarda i Virginii Woolfów mieszczącą się w Rodmell, niedaleko Lewes w południowej Anglii. 
Bez wątpienia odkładanie pracy, nawet jeśli nieco zabobonne, wskazuje, że mimo ogromnego pragnienia, by napisać tę powieść, dręczył ją temat, który wybrała. Niewiele ponad trzy lata później pewna data stała się pretekstem do podobnego wyznania. 28 listopada 1928 roku pisze w dzienniku: „Urodziny ojca [...] Był czas, kiedy myślałam o nim i o matce co dzień; ale pisanie Do latarni morskiej pochowało ich w moim umyśle. (Sądzę, że tak było naprawdę - że byłam obojgiem jakoś niezdrowo opętana; że pisanie o nich było koniecznością)" (D3 208 [352]). Gdy rozmyślała o zbliżającym się pierwszym dniu pobytu w Monks House, jej nastawienie było przesadnie optymistyczne: „Wydaje mi się, że tam powinnam to napisać w ciąu dwóch miesięcy” (D3 36 [279]).Zgodnie z planem umieszcza w nagłówku brudnopisu datę 6 sierpnia ${ }^{3}$. Trzeba było jednak nie dwóch miesięcy, lecz prawie dwóch lat, by ukazało się pierwsze wydanie Do latarni morskiej, które 5 maja 1927 roku wyszło równocześnie w Wielkiej Brytanii i Stanach Zjednoczonych ${ }^{4}$.

Zanim Woolf rozpoczęła pisanie Do latarni morskiej, zanotowała swoje przemyślenia na temat powieści w Notatkach do powieści [Notes for Writing]. Wyobrażenie struktury dzieła przedstawiła w formie litery $\mathrm{H}$ odpowiadającej graficznie trzem rozdziałom ostatecznie zatytułowanym Okno - Czas płynie - Latarnia ${ }^{5}$. Pionowe linie litery H reprezentują kolejno pierwszy, obejmujący jeden dzień, odcinek narracji (w którym kończy się obecność pani Ramsay w powieści) oraz trzeci odcinek obejmujący większą część innego dnia (w którym pan Ramsay, James i Cam płyną do latarni morskiej, a Lily Briscoe kończy swój obraz: „Dokonała tego, co chciała. Obraz był skończony. Odkładając pędzel z ostatecznym wyczerpaniem, pomyślała: Przeżyłam swoją

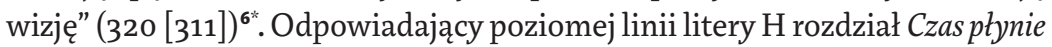
tworzy łącznik (corridor) (takiego określenia używa Virginia Woolf) między tymi dwoma dniami. Łączy on zmierzch dnia opisanego w pierwszym rozdziale z porankiem w rozdziale trzecim. Wypełnia więc czas zaledwie jednej nocy, lecz czyni to w sposób nieciągły, niemal bez symbolicznych szczegółów.

3 Kalendarz ściśle wiąże twórczość Virginii Woolf z jej życiem osobistym. Daty regularnie pojawiają się w rękopisach pisarki, podobnie też z każdym kolejnym wpisem wyznaczają etapy rozwoju pisanego przez nią dziennika.

4 Teksty obu edycji różnią się nieznacznie; przedstawię tę kwestię dalej.

5 Zob. fotokopię notatnika na www.woolfonline.com/.

6 V. Woolf To the Lighthouse, Hogarth Press, London, 1927; V. Woolf Do latarni morskiej, przeł. K. Klinger, Warszawa 1962. Numery stron w nawiasie odsyłają kolejno do wydania angielskiego, oraz do polskiego tłumaczenia (w nawiasie kwadratowym). 
W istocie narracja wykorzystuje podwójną strukturę czasową. Czas ptynie rozdziela wieczór opisany w pierwszym rozdziale od poranka rozdziału trzeciego o dziesięć lat. To katastrofalne lata wypełnione śmiercią członków rodziny i wojną na świecie. Podział środkowej części powieści na dziesięć segmentów umożliwia przekształcenie tych dziesięciu lat w strukturę narracyjną.

Już od samego początku obserwujemy zatem dwa bodźce wpływające na pomysł i kompozycję Do latarni morskiej: intensywną autobiograficzną refleksję oraz misterny, szczegółowy projekt struktury. Bodźce te jedynie z pozoru są niewspółmierne, w rzeczywistości charakteryzują istotę spojrzenia Virginii Woolf na sztukę powieści, która powinna opowiadać o życiu i cechować się kunsztowną formą. Co więcej, jak widzieliśmy, pisarka uświadomiła sobie, że po latach codziennych, przytłaczających myśli o rodzicach pisanie i praca nad kompozycją Do latarni morskiej pozwoliły jej „pochować ich w umyśle”. Ale, odkładając na bok autopsychoterapię, właściwie w jaki sposób można osiągnąć taki efekt za pomocą środków artystycznych? W jaki sposób stworzona na gruncie autobiograficznym fikcja może uzyskać, tak jak uzyskuje w tym konkretnym przypadku, autonomię dzieła sztuki? Szczęśliwie posiadamy obszerną dokumentację dwuletniego procesu pisania zwieńczonego ukazaniem się pierwodruków powieści. Dostarcza ona ważnych wskazówek dotyczących formowania, przekształcania i powstawania różnych wersji znajdujących się u podstaw przeobrażenia pamięci w fikcję.

Virginia Woolf miała pełną świadomość kompozycji swoich dzieł i doskonale je pod tym względem kontrolowała. Do latarni morskiej jest tego znakomitym przykładem, który ukazuje także, że pisarka chciała, by odbiorcy dostrzegli jej kunszt. W tekście umieściła wskazówki. Chodzi o miejsca, w których powieść odwołuje się do siebie samej, np. Lily Briscoe, malarka, powszechnie uważana jest za artystyczne alter ego pisarki, zaś ukończony przez nią obraz uznaje się za odpowiednik powieści, jej „obiektywny korelat” (objective correlative) czy też korelatywny obiekt i czynnik znaczący znajdujący się wewnątrz fabuły. Opowieść kończy się sceną, w której Lily Briscoe „odkłada pędzel z ostatecznym wyczerpaniem". To uczucie towarzyszące zakończeniu pracy sugestywnie oddaje stan umysłu i ciała Virginii Woolf $\mathrm{w}$ chwili ukończenia powieści - tej lub każdej innej, jaką napisała. Projekcja autobiograficznego literackiego „ja” autorki na fikcyjną postać do wyczerpania praktykującą siostrzaną sztukę, malarstwo, ma kluczowe znaczenie w procesie ustanawiania autonomii świata fikcji. By ukończyć obraz, Lily Briscoe (tuż przed odłożeniem pędzla) „spojrzała na płótno - było zamazane. Z nagłym 
napięciem, jakby przez chwilę dane jej było bezbłędne widzenie, przeciągnęła pędzlem przez środek płótna" (320 [311]). Innymi słowy, fikcyjna malarka podkreśla centrum obrazu z tym samym poczuciem pewności, z jakim rzeczywista pisarka na samym początku „nakreśliła linię”, by w kształcie litery $\mathrm{H}$ przedstawić zarys struktury przyszłej powieści. Zakończenie potwierdza więc słuszność uniezależnienia od siebie dwóch dni opisanych w rozdziałach Okno i Latarnia oddzielonych dziesięcioletnim okresem, który obejmuje rozdział Czas ptynie. Co ciekawe, Virginia Woolf sama wyznała w swoim dzienniku, że jej wyczucie, jak zakończyć powieść, było całkiem zamazane jeszcze na trzy tygodnie przed szacowanym ukończeniem wersji brulionowej: „Miałam zamiar zakończyć obrazem R. wspinającego się po skale. Gdybym tak zrobiła, co stałoby się z Lily i jej obrazem?" (D3 106) $)^{7^{*}}$. Moment klarownej wizji musiał zaowocować decyzją pisarki, by nie budować zakończenia na poziomie fabuły i postaci, lecz na metapoziomie wewnętrznego odwołania do struktury powieści.

"Przeciągnięcie pędzlem przez środek płótna” jest tropem wskazującym na możliwe do wyśledzenia powracające symetryczne struktury. Na przykład centrum całej powieści stanowi środkowy rozdział Czas ptynie, podobnie też rozdział ostatni, Latarnia, zogniskowany jest wokół środkowej, siódmej z trzynastu części ${ }^{8}$. Dowiadujemy się o tym dzięki refleksji Lily Briscoe: „spojrzała na leżącą u swych stóp zatokę [...] uwagę jej zwróciło coś nie pasującego do tego widoku: pośrodku zatoki widać było jakąś brązową plamkę [...] była to łódź [...] Pana Ramsaya [...] Łódź była pośrodku zatoki" (279-28o [271]). Co ważne, pomysł, by zogniskować trzeci rozdział wokół jego środkowej części opisującej łódź pośrodku zatoki, powstał dość wcześnie. W brulionie Latarnia obejmuje jedynie dziewięć części. Już tutaj to, co później stanie się częścią siódmą rozbudowanej narracji, należy do środkowej, piątej części brudnopisu - jest w niej także łódź pośrodku zatoki. Siódma część w książce już ukończonej składa się ostatecznie z tekstu przeniesionego z części piątej

7 Cytowany fragment pominięto w polskim, skróconym wydaniu dzienników.

8 Na skutek odkrytego całkiem niedawno błędu drukarskiego wprowadzonego do brytyjskiego pierwodruku powstało wiele nieporozumień co do ilości części składających się na rozdział Latarnia. W rzeczywistości jest ich trzynaście.[Pierwsze polskie wydanie powieści z 1962 roku podąża najwyraźniej za błędnie numerowaną edycją brytyjską, podając czternaście części. W konsekwencji w wydaniu tym opisywanej przez autora części siódmej odpowiada część z numerem ósmym. Poprawna numeracja obowiązuje w pozostałych dwóch wydaniach przekładu Klingera opublikowanych nakładem wydawnictwa Czytelnik w 2000 oraz 2005 roku przyp. tłum.] 
i połączonego krótkim fragmentem wtrąconej w nawiasie narracji stanowiącej zwięzły kontrapunkt dla obrazu przemierzającej zatokę łodzi (por. 277-278 [269]). Parentetyczne wtrącenia są charakterystycznym zabiegiem narracyjnym Woolf, często przez nią używanym zarówno w tej powieści, jak i w innych jej tekstach.

Głębsze zrozumienie kolejnych etapów kształtowania struktury narracji można uzyskać, śledząc moment, w którym za sprawą zmian w rozdziale Latarnia wyodrębniła się część siódma. Część piąta kończy się rozmyślaniem Lily Briscoe o tym, że gdyby wraz z panem Carmichaelem „krzyknęli dostatecznie głośno, pani Ramsay by wróciła. - Pani Ramsay! - powiedziała głośno Lily - pani Ramsay! - a łzy toczyły się po jej twarzy" (277 [268-269]). Część siódma zaczyna się słowami „Pani Ramsay! - zawołała Lily - pani Ramsay! - Lecz nic się nie działo - tylko wzrastał jej ból. Udręka potrafi zaprowadzić człowieka na samo dno głupoty - rozmyślała" (278 [269]). Jednak w miarę jak głupota ustępuje, pojawia się wizja:

dziwna świadomość czyjejś obecności - chyba pani Ramsay; stała lekko (była to pani Ramsay w całej krasie swej urody) przy boku Lily i uwolniona od ciężarów, które świat na nią nakładał - podnosiła do czoła wieniec białych kwiatów, które zabrała ze sobą, gdy odchodziła.

Lily wycisnęła tubkę z farbą. Znów wróciła do problemu żywopłotu. Jakie to było dziwne, że tak wyraźnie widziała ją, jak szła przez pole swym zwykłym szyblim krokiem, by zniknąć wśród miękko-purpurowych zagonów, na których rosły hiacynty czy lilie. Niezawodnie było to złudzenie malarskiego oka. (278-279 [270])

Jest to rzeczywiście malownicza wizja, istne „złudzenie malarskiego oka”. Nade wszystko jest to bez wątpienia wizja Lily Briscoe w pełni określająca ją jako postać fikcji zatytułowanej Do latarni morskiej. Siódma część precyzyjnie skomponowanego rozdziału Latarnia tworzy w ukończonym dziele punkt kulminacyjny. Dystansując się od własnych silnych emocji za pomocą autoironicznego realizmu („Czy brakowało jej pani Ramsay, gdy piła kawę przy śniadaniu? Bynajmniej" (278 [270]) $\left.)^{9 *}\right)$ Lily dostrzega możliwość przekształcenia wizji w malarskie spełnienie. Wrażenie obecności pani Ramsay zmienia się w jej niknący obraz: „idzie przez pole z cieniem - swoim milczącym towarzyszem" (279 [270]). Lily rozumie korzyść, jaką odniosła dzięki

Przekład nieznacznie zmodyfikowany. 
wizjom, w których pani Ramsay powracała nieustannie od chwili swojej śmierci - uwolniły one jej zmysł artystyczny oraz zdolności twórcze. „Teraz także, wiedziona instynktowną potrzebą przestrzeni i błękitu, spojrzała na leżącą u swych stóp zatokę, na której błękitne pasma fal z rozdzielającymi je purpurowymi płachtami wody wyglądały niby wzgórza poprzegradzane kamienistymi polami" (279 [271]). Wody wypełniające zatokę przekształca w obraz lądu: barwa fal, którą obserwuje, przybiera na płótnie postać wzgórz i kamienistych pól. Wszystko to dzieje się w chwili, gdy Lily jest tak głęboko pogrążona w procesie twórczym, że „[j]ak zwykle uwagę jej zwróciło coś nie pasującego do tego widoku" - dostrzegła łódź pośrodku zatoki (280 [271]). By w pełni docenić jakość kompozycji, która cechuje ukończoną postać tego fragmentu, należy, po pierwsze, zauważyć, że rozwój narracji kształtowany jest zarówno przez kategorie formy, jak i podobnie mocne kategorie treści; po drugie, że wszystkie jego elementy podlegają malarskiej wizji Lily Briscoe; po trzecie, że wizja ta składa się zarówno ze składników wyobrażonych, jak i rzeczywistych. Do największego artystycznego osiągnięcia Virginii Wolf doszło przede wszystkim dzięki przetworzeniu pamięci oraz rozwijanej opowieści w autonomiczną fikcję.

W pierwszym rzucie zapis tego, co utrwalone w pamięci, często przenosi osobisty charakter wspomnień. Odkąd został on wyrażony w języku, funkcjonuje jako pamięć utrwalona za pomocą znaków. W efekcie wierzymy, że obserwując genetyczną ewolucję fikcyjnego tekstu, jesteśmy w stanie dostrzec, jak pamięć zawarta w znakach zostaje stopniowo pozbawiona, oczyszczona z wciąż jeszcze prywatnej wrażliwości, przetworzona z zewnętrznej perspektywy. Można to wywnioskować z brulionu powieści. Właśnie tutaj bardziej niż w późniejszych dokumentach poprzedzających publikację dzieła widać, że literackie, zwłaszcza poetyckie, bogactwo artystycznych tekstów Wolf wynika z podwójnego doświadczenia: uwalniania się od osobistych wspomnień, tak intensywnych, że wyrażonych za pomocą języka, oraz doświadczenia potęgi wyobraźni, która pozwala pisarce uczestniczyć w rozwijających się wydarzeniach i utożsamiać się z postaciami, które tworzyła.

Końcowa partia (obecnie) części piątej (od słów: „Wbrew swej woli Lily wypłynęła z zatoki rozmyślań" (274 [265]) wraz z (obecnie) częścią siódmą ${ }^{10^{* *}}$ odsyłają do stron 220-225 brulionu, w którym układają się w jednolity ciąg

10 W cytowanym tłumaczeniu są to odpowiednio części szósta i ósma. 
tekstu tworzonego przez pięć (lub cztery?) dni ${ }^{11}$. Jeden fragment brudnopisu musi wystarczyć do ukazania, że już we wczesnej fazie powstawania dzieła Lily Briscoe emocjonalnie postrzega rzeczywistość przez pryzmat każdego poruszającego ją szczegółu:

Patrzyła na schodki do salonu [...] Były puste [...] Dotarło do niej [...] wyraźnie, po raz pierwszy [...] nikt tam nie siedział. Ozdobne okrycie krzesła znajdującego się w pokoju drgnęło lekko poruszone wiatrem [...] Jak w przypadku wszystkich silnych uczuć, fizyczne odczucie [...] było [...] szalenie nieprzyjemne. Pragnąć i nie móc mieć, wywołało to w jej ciele uczucie sztywności, czczości i napięcia [...] jak to dręczyło umysł, jak ściskało serce, zostawiając je niczym skórka wyciśniętej pomarańczy. I znów pragnąć i nie móc mieć - pragnąć, stale pragnąć! O, pani Ramsay - zawołała po cichutku, jakby mogła ją zelżyć za to, że odeszła i w ten sposób zakłóciła jej malowanie i dręczyła ją tym cierpieniem [...] Czemu to zrobiła? Duch, powietrze, nicość - \{-do dziś Lily nie myślała o niej od wielu miesięcy. Teraz się wydawało, jakby pani Ramsay dla własnych celów tylko pozwalała któremuś duchowi chwilę poigrać.- $\}$ Pragnęła, by wrócił. I wrócił. Była tylko tym [...] Wtem niespodziewanie ocknęła się i puste schodki do salonu i powiewające ozdobne okrycie krzesła, i szczeniak turlający się po tarasie - wszystko to przypominało [...] niczym puste $\{+$ spirale $i$ arabeski+ $\}$ skaczące, ziejące, $[\ldots]\{+$ nieskończone+ $\}$ upragnione zjawy skupione wokół całkowitej pustki. ${ }^{12}$

Odczytujemy ten fragment, mając w pamięci tekst Do latarni morskiej zawarty w książce. Rozpoznajemy znane frazy oraz odległe echa innych sformułowań, obserwujemy falstarty lub odczuwamy napięcie wynikające z niektórych fragmentów zdradzających w brulionie potencjał niewykorzystany

11 Terminus ad quem to 17 sierpnia 1926 roku, data umieszczona w rękopisie dwukrotnie - na końcu omawianego fragmentu oraz na początku kolejnego. Okres, jaki bierzemy pod uwagę, rozciąga się od 13 (lub 14) do 17 sierpnia 1926 roku i najprawdopodobniej obejmuje rękopiśmienne karty o numerach 220, 221, 222-223, 224, 225. Cyfrowe fotokopie rękopisu wraz z transkrypcją dostępne są na stronie www.woolfonline.com/. towym oznaczono miejsca, w których pominięto fragmenty zarzucone lub skreślone; od tej reguły zastosowano dwa wyjątki: nawias $\{-\ldots-\}$ wskazuje skreśloną lekcję alternatywną, zaś nawiasem $\{+\ldots+\}$ oznaczono słowa dodane do tekstu. Nie jest to oczywiście transkrypcja ukończonego tekstu, lecz wciąż postępującego zapisu. 
w tekście. Równocześnie wydaje się, że brulion potwierdza coś, co zostało wyrażone w dziele, które znamy. Kontakt z brulionem pozwala nam zobaczyć doświadczenie intelektualne i estetyczne, które równocześnie jest doświadczeniem tego, „co czuje ciało”, jest to „uczucie ciała, a nie umysłu” (274-275 [266 13"] $)$. Niewykluczone, że ku naszemu zdumieniu, śledzenie procesu twórczego wzbudza w nas podobne cielesne odczucia, które z kolei umożliwiają nam lepsze zrozumienie, w jaki sposób pisarstwo Virginii Woolf, tak zmienne $\mathrm{w}$ procesie tworzenia, powstaje wprost $\mathrm{z}$ cielesnych odczućc ${ }^{14}$. Równocześnie jednak uczucie to za sprawą niezawodnej świadomości estetycznej podlegało stopniowemu kształtowaniu, zostało także intelektualnie podporządkowane rygorom strukturalnym oraz konieczności zdystansowania się od opisywanych wydarzeń. Energia wyzwolona za sprawą estetycznego i intelektualnego zdystansowania odpowiedzialna jest za to, co z zapisów brulionowych „zachowało się" w opublikowanym dziele, a także za odrzucenie pierwotnych pomysłów.

W jaki jednak sposób możemy te cielesne odczucia odczytać w brulionie i za jego pośrednictwem? Nie ma wątpliwości, że to właśnie cielesne odczucia Lily Briscoe są kształtowane, formowane w postaci tekstu z myślą o ich wykorzystaniu w powieści, są tworzone j a ko fikcja. Jakie są źródła, z których wypływa akt twórczy wyrażony za pośrednictwem języka? Brulion ujawnia - co staram się podkreślić - że pisząc, autorka Virginia Woolf w znacznym stopniu czerpała z własnych „emocji ciała”. Oczywiście jako doświadczona i wprawna pisarka od początku projektowała Lily Briscoe jako postać powieściową z metafikcjonalnej perspektywy jako postać kluczową. Równocześnie z tego właśnie powodu oraz przez utworzenie wspomnieniowej relacji między Lily a panią Ramsay (zadaniem Lily jest właśnie przypomnienie i ożywienie jej za pomocą wyobraźni) Virginia Woolf wyzwala uczucia wła s n e go ciała i własnej pamięci. Z łatwością możemy to wywnioskować, czytając brulion: „Patrzyła na schodki do salonu[.] Były puste [...] Dotarło do niej wyraźnie, po raz pierwszy [...] kogoś tam brakowało [...] Jak w przypadku wszystkich silnych uczuć, fizyczna reakcja [...] była [...] szalenie nieprzyjemna. Pragnąć i nie móc mieć, wywołało to w jej ciele uczucie sztywności, czczości i napięcia [...] I znów pragnąć i nie móc mieć - pragnąć, stale pragnąć! O, pani

13

Cytat nieznacznie zmodyfikowany.

Zob. M. Cuddy-Keane Movement, space, and embodied cognition in "To The Lighthouse", w: The Cambridge Companion to "To the Lighthouse", ed. by A. Pease, Cambridge University Press, Cambridge 2015 . 
Ramsay - zawołała po cichutku, jakby chciała ją zelżyć za to, że odeszła i w ten sposób zakłóciła jej malowanie i dręczyła ją tym cierpieniem". Zastąpienie w ostatnim zdaniu "malowania” słowem „pisanie” i „panią Ramsay” słowem "matka”, ukazuje, że słownictwo wskazujące na udręczenie wyraża poczucie własnego „ja” Virginii Woolf powracające w jej życiu i praktyce twórczej.

Doświadczenie wyłaniającej się formy prowadzi więc do ważnego rozróżnienia. Dostrzegamy bowiem, że ewokowana w brulionie udręka rodzi się przede wszystkim na skutek procesu pisania. Na tym etapie nie jest to w pełni i w sposób autonomiczny - udręka bohaterki powieści. W trakcie pisania Virginia Woolf pozwala swoim prywatnym wspomnieniom i cielesnym emocjom przekształcać się w materię językową. To właśnie wtedy za sprawą twórczej siły pisarki struktura językowa zostaje przekształcona w fikcyjny obraz i narrację. Pod wpływem korekt i dalszej pracy twórczej, wykraczającej poza brulion, zapisane emocje i wspomnienia przestają mieć charakter osobisty. Stają się emocjami i wspomnieniami Lily Briscoe, dopełniającymi autonomię tej postaci w powieści.

W przypadku Virginii Woolf proces pisania oraz stałe poprawianie tekstu wiedzie (zazwyczaj) od brudnopisu przez maszynopis autorki, kopię wydawcy, korektę autorską, korekty wydawnicze i zakończony jest wraz z ukazaniem się tekstu w pierwszym wydaniu książkowym. Gdy chodzi o Do latarni morskiej, materiały pośrednie między brulionem a korektami wydawniczymi nie zachowały się $e^{15}$. Jedynie na podstawie zakresu, stopnia i jakości różnic, jakie występują między brulionem a korektami, można oszacować, jak tekst przekształcał się od zapisów o charakterze osobistym w autonomiczną fikcję opowieści jako całości. W pierwszym przykładzie przytoczonym za tekstem książki Lily Briscoe widzi, jak pani Ramsay „szła przez pole swym zwykłym szybkim krokiem, by zniknąć wśród miękko-purpurowych zagonów, na których rosły hiacynty czy lilie". Zdanie to jest esencją utrwalonego w brulionie procesu pisania rozpoczętego jednego dnia i podjętego niemal od nowa w dniu następnym, co zaowocowało znaczną ilością zapisanego materiału (por. s. 222-223 i $224 \mathrm{w}$ brulionie). Jest to jedna z wielu wizji ukazujących panią Ramsay, które narracja przypisuje Lily Briscoe. W zachowanych świadectwach procesu pisania wysiłek związany z przywoływaniem tych wizji został poddany refleksji:

15 Z jednym wszakże wyjątkiem - dysponujemy profesjonalnie przygotowanym maszynopisem drugiego rozdziału, stanowiącym niezależną wersję środkowej części powieści. Będzie o nim mowa w dalszej części artykułu. 
Gdziekolwiek była, w Londynie czy na wsi, jej oko, na pół przymknięte, stale szukało w realnym świecie jakiegoś odpowiednika, czegoś, co pomogłoby jej wyobraźni; i znajdowała to na Piccadilly, na Bond Street, a także na wrzosowisku i we wszystkich wzgórzach, które wieczorem bledły. [nota na marginesie: skojarzenie z polami śmierci] [...] Wszystko to nagle zniknęło. Zawsze jednak było tak samo [...] Nie śnij, nie patrz, rzeczywistość powstrzymywała ją, docierając do niej z nieoczekiwanego załomu lub cienia, czegoś, czego nie mogła w swoich myślach oswoić. (s. 223 brulionu)

To pełne udręki pisanie wyraża stan udręczonego umysłu. A może ujawniająca się za pośrednictwem języka udręka jest spowodowana napięciem wywołanym przekształcaniem wizji w słowa podczas pisania? W pewnym sensie fragment ten przypomina zbiór notatek do tekstu, który dopiero ma zostać napisany. Patrząc retrospektywnie, rozpoznajemy, że partia o czymś, "co pomogłoby jej wyobraźni; i [znajdowaniu tego] na Piccadilly, na Bond Street", została pomyślana na nowo, wzmocniona przez dodanie większej liczby szczegółów i ostatecznie zapisana w następującej postaci:

Gdziekolwiek była [...] na wsi czy w Londynie, wizja ta stale się jawiła [...] rozglądała się po wagonie kolejowym lub po autobusie [...] wpatrywała się w okno po drugiej stronie ulicy lub obserwowała Piccadilly, omotaną wieczorem liniami świateł. Wszystko to było częścią pól śmierci. Lecz zawsze coś: czyjaś twarz, głos lub krzyk gazeciarza, sprzedającego "Standard” czy „News”, przebijał się do jej świadomości, budził ją zmuszając w końcu do uwagi - wizja musiała być stale tworzona na nowo. $\left(279\left[270-271^{16^{*}}\right]\right)$

Gdy przyjrzymy się bliżej, staje się jasne, że podczas obmyślania na nowo i przekształcania jednego fragmentu w drugi autorka odwróciła kierunek myśli. Zapisana w brulionie partia, której kulminacja zamyka się w słowach „Nie śnij, nie patrz, rzeczywistość powstrzymywała ją”, sprawia wrażenie napisanej pod wpływem prawdziwej sytuacji: rzeczywistość musi trzymać w szachu i rozwiewać wizje, które nie są przez umysł „oswojone”. Codzienna rzeczywistość jest oczywiście w ukończonym tekście obecna: „przebija się i zmusza w końcu do uwagi", ale stanowi tylko chwilową przeszkodę, dzięki

Przekład nieznacznie zmodyfikowany. 
której „wizja musiała być stale tworzona na nowo”. W trakcie dobierania słów wyrażone w brulionach podobieństwo empirycznej rzeczywistości Virginii Woolf zmienia się w świadomość źródła własnej twórczości, którym jest właśnie „wizja [...] stale tworzona na nowo”. Świadomość ta należy równocześnie do pisarki oraz jej literackiego sobowtóra: na poziomie narracji do Lily Briscoe, zaś na poziomie dzieła do Virginii Woolf, której tekst zdradza fundamentalną zależność jej sztuki od „wizji [...] stale tworzonej na nowo”.

Rozważając, w jaki sposób Virginia Woolf przekształca materię pamięci w fikcję, rozpoznajemy, że pisarka funkcjonuje na dwóch poziomach działania sił twórczych. Jako Virginia Woolf z powodzeniem wchodzi w relację z panią Ramsay jako Julią Stephen, mając w pamięci swoje rzeczywiste stosunki z matką oraz wizje, jakie pojawiały się przez wszystkie lata od czasu jej śmierci. Równocześnie, jako pisarka, tworzy postaci, takie jak pani Ramsay czy Lily Briscoe, które w pełni należą do fikcyjnego świata powieści. Ponadto wyobraża sobie Lily Briscoe, tak emocjonalnie, jak emocjonalnie uprawia swoją sztukę, przez co utożsamia się z nią, czyniąc z niej swoje odbicie, stopniowo nadając jej autonomię $\mathrm{w}$ trakcie pisania i redagowania dzieła"

Nieustanne tworzenie od nowa stanowi istotę genezy tekstów oraz dzieł literackich. Zauważalne fakty dotyczące tworzenia i przekształcania Do latarni morskiej przez Virginię Woolf przedstawiłem w osobnym studium przede wszystkim pod kątem krytyki tekstu i edytorstwa, zwracając uwage na ich istotne znaczenie dla badań ${ }^{18}$. Najważniejszym momentem w historii zmian tekstu było usunięcie w ostatniej chwili dwóch i pół strony z arkuszy korekty wydawniczej ${ }^{19}$. Pozornie operacja ta była możliwa jedynie w angielskich warunkach wydawniczych. Dzięki usunięciu tych złamanych już stron pierwsze brytyjskie wydanie mieściło się na szesnastu arkuszach, czyli obejmowało 320 stron. Nie należy jednak rozpatrywać tego przypadku wyłącznie w kategoriach bibliologicznych, ponieważ jako akt rewizji (re-wizji) znacząco zmienia on znaczenie związku łączącego Jamesa z panem Ramsayem.

17 Hermione Lee we wstępie do edycji powieści przedstawia liczne obserwacje i refleksje wzbogacające przeprowadzoną w niniejszym szkicu analizę genetyczną. Zob. V. Woolf To the Lighthouse, ed. by S. McNichol, Penguin, London 1991. A tale of Two Texts: Or, How One Might Edit Virginia Woolf's "To the Lighthouse", "Woolf Studies Annual" 2004 vol. 10, s. 1-30. 
Fragment, o którym mowa, opisywał wspomnienia Jamesa dotyczące ponurych czasów po śmierci matki, kiedy, przymuszony przez ojca, musiał wraz z rodzeństwem towarzyszyć mu w męczących podróżach na wykłady odbywające się w całym Londynie. Porównanie arkuszy korektowych z brulionem ujawnia ślady pracy nad tą partią tekstu. Na przykład w korekcie refleksja i akcja skupione wokół Jamesa są połączone, natomiast wcześniej rozdzielono je między Jamesa i jego młodszego brata, Jaspera. $Z$ drugiej strony porównanie fragmentów znajdujących się powyżej usuniętej partii z fragmentami znajdującymi się poniżej ujawnia dwie rzeczy. Wycięcie wyeliminowało bodaj ostatni ustęp utrwalający w niewielkim już stopniu pamięć o rzeczywistym życiu rodzinnym pisarki. W konsekwencji nastąpiła zmiana - tak nagła, jak decyzja pisarki o usunięciu fragmentu - stosunku Jamesa do ojca. Podczas podróży do latarni morskiej James usilnie walczy ze swoimi emocjami i odczuwaną w stosunku do ojca nienawiść zaczyna zastępować miłością. Ponadto narracja wzmacnia tę wewnętrzną przemianę poprzez rozwój akcji. To właśnie James, dojrzały młody mężczyzna, jakim już się stał, bezpiecznie steruje łodzią przez zatokę, zdobywając tym samym uznanie ojca. Wspomnienie ponurych londyńskich lat nie pasowało do tak prowadzonego rozwoju postaci, którego kulminacją było postanowienie Jamesa, by nie stać się takim jak ojciec. Usuwając partię wspomnieniową, Virginia Woolf potwierdziła ostatecznie dojrzałość bohatera, którą - jak zorientowała się podczas ponownej lektury - zdążyła już w powieści zaznaczyć. Podobnie jak w przypadku stopniowego formowania fikcyjnej autonomii Lily Briscoe, tak i tutaj dostrzegła konieczność pełnego zharmonizowania narracji z wewnętrzną logiką postaci Jamesa, który nie powinien być pozostałością obrazu jej młodszego brata Thoby'ego, lecz musiał stać się autonomiczną postacią fikcyjnego świata Do latarni morskiej.

Polecenie usunięcia fragmentu powieści zostało przekazane także do amerykańskich wydawców, obie edycje są zatem identyczne pod względem braku reminiscencji ponurych lat spędzonych w Londynie. Jeśli jednak wziąć pod uwagę inne, zwykle mniej znaczące, lecz w pewnych przypadkach bardzo istotne szczegóły, różnica między tymi wydaniami jest zamierzona $^{20}$. Brytyjski oraz amerykański pierwodruk są zatem osobnymi

20 Książki wywodzące się z Wielkiej Brytanii i posiadające brytyjski copyright mogły uzyskać copyright w Ameryce pod warunkiem ich ponownego składu i wydania w Stanach Zjednoczonych. Ponadto powszechnie wierzono - Virginia Woolf podzielała to przekonanie - że konieczne były także pewne zmiany w tekście. 
wersjami powieści. To rozróżnienie, wynikające z licznych wariantywnych ustępów, znajduje potwierdzenie w różnych w obu wydaniach zakończeniach rozdziału $O k n o^{21}$.

W trakcie pisania Do latarni morskiej Virginia Woolf już raz skomponowała dwie wersje tekstu. Siła twórcza wyzwolona podczas pisania „Części drugiej” powieści pozwoliła jej na stworzenie odrębnej wersji. Pierwszy szkic „Części drugiej" był ukończony między 30 kwietnia a końcem maja 1926 roku. Pracując nad ukończeniem „Części trzeciej”, zaryzykowała równocześnie stworzenie alternatywy dla „Części drugiej”, jeszcze zanim na jej podstawie, nawet wbrew niej, stworzyła umieszczony ostatecznie w powieści rozdział $C z a s$ ptynie. Wersja alternatywna zachowała się w profesjonalnym (zawierającym drobne autorskie poprawki) maszynopisie sporządzonym w październiku 1926 roku. Był on podstawą przekładu na język francuski²2. To właśnie w tym maszynopisie po raz pierwszy pojawia się tytuł $C$ zas ptynie. Przekazany w nim tekst stanowi wersję środkowego rozdziału Do latarni morskiej, a równocześnie w kontekście całości literackiego dorobku Virginii Woolf można porównać go np. do samodzielnych krótkich opowiadań, które powstały przy okazji pisania Pani Dalloway.

Zaledwie po jednym dniu pracy nad „Częścią drugą” Virginia Woolf zanotowała w dzienniku: „Nie potrafię tego wymyślić - to jest najtrudniejszy, abstrakcyjny fragment - muszę oddać pusty dom, bez żadnych postaci ludzkich, upływ czasu, wszystko bez oczu i rysów twarzy, bez żadnego punktu zaczepienia" (D3 76 [295]). Początek rozdziału informuje, że leje deszcz, jest noc, domownicy śpią. Wkrótce pocieszycielskie duchy uniosą ich z łóżek i ułożą, wciąż śpiących, na plaży. Dom jest teraz pusty i, w miarę upływu czasu, pozostawiony na pastwę zniszczenia i rozkładu pod wpływem sił natury, bujnej fauny i flory, niszczycielskiego działania wiatru i wody. Od tego momentu rozchodzą się trzy linie narracji. Jedna wiąże się z ruiną domu i rozrostem ogrodu, druga z losami rodziny w czasie lat rozciągających się między początkiem a końcem rozdziału, trzecia natomiast łączy się ze zmaganiami pani McNab i pani Bast - które także są częścią sił natury - zabiegającymi o to, „by ostatecznie dom nie zapadł się w głąb i nie osiadł na piaskach zapomnienia" (215 [207]). Ta potrójna struktura zarysowała się w brudnopisie i - jak

21

22

Omawiam to zagadnienie w artykule $A$ tale of Two Texts...

Okoliczności powstania przekładu zostały omówione we wstępie do edycji V. Woolf To the Lighthouse, ed. by S. Dick, Oxford University Press, Oxford 1992, s. XXXVIII. Apendyks C zawiera transkrypcję maszynopisu, który jest także dostępny na stronie www.woolfonline.com/. 
widać - przetrwała jako kluczowy element kompozycji w drukowanej postaci rozdziału Czas ptynie.

Maszynopis różni się od poprzedzającego go brudnopisu silną dominacją pierwiastka nadprzyrodzonego, widmowego nad wszystkim, co ludzkie, a także nad siłami natury. Cały czas te „duchy powiernicze, towarzysze, pocieszyciele" zdają się wszechobecne w domu, w ogrodzie, na plaży oraz w wielu kluczowych momentach narracji, śpiący domownicy są z nimi wyraźnie związani mistyczną nicią porozumienia aż do momentu, gdy nastaje kres ich królestwa, kiedy wszystko się rozprasza, dokładnie w tym momencie, kiedy noc znów zmienia się w dzień. Przekazana w maszynopisie wersja rozdziału Czas płynie jest w całej swojej złożoności tekstem wizjonerskim. Być może w żadnym innym dziele Virginia Woolf tak intensywnie nie poszukiwała i nie odnalazła wyrazu dla euforii towarzyszącej zakończeniu I wojny światowej oraz dla obietnicy świetlanej przyszłości, którą zapewnić miał pokój. Niemniej jednak widmowy wymiar utrwalonego w maszynopisie rozdziału $C z a s$ ptynie (dyskretnie) osłabiałby zamierzony realizm Do latarni morskiej, dlatego wersja przeznaczona do publikacji wygrała ze swoim niezależnym bliźniaczym odpowiednikiem. Gdy jednak porównujemy oba teksty, głos wersji z maszynopisu wydobywa się z niebytu i wzbogaca nasze rozumienie tego rozdziału oraz poszerza wymowę całej powieści ${ }^{23}$.

Przełożył Łukasz Cybulski

23 Przeredagowanie ostatniej partii maszynopisu (część IX) i powstanie jej odpowiednika w rozdziale Czas płynie (część X) daje podstawę ciekawej hipotezy. Fragment, który w maszynopisie brzmi: „[śpiący] byli już całkiem rozbudzeni; byli wyprostowani; ich oczy były otwarte; nastał dzień", w powieści odnosi się do Lily Briscoe, której „oczy [...] rozwarły się szeroko. Oto znów tu jestem - pomyślała siadając w łóżku rozbudzona" (V. Woolf Do latarni morskiej, s. 214). Jeśli jest to reminiscencja Snu nocy letniej: "Czemu zatem nie śpimy", kiedy o świcie kochankowie budzą się po nocnych igraszkach, można by, zważywszy zamiłowanie Virginii Woolf do Szekspira, rozpatrywać strukturę rozdziału Czas płynie jako nawiązanie do Szekspirowskiego dramatu. 


\section{Abstract}

\section{Hans Walter Gabler}

LUDWIG MAXIMILIAN UNIVERSITY OF MUNICH

From Memory to Fiction: An Essay in Genetic Criticism

Gabler reconstructs and analyses the creation of Virginia Woolf's novel To the Lighthouse with a focus on the third section,'The Lighthouse'. The novel's structure and publication history are discussed alongside the rich sources on the text's genesis, (auto)biographical materials and Woolf's drafts. These drafts, although only few of them survive, shed light on the early development of her prose. Gabler's analysis shows how Woolf departed from her personal experience - traces of which are visible in the earliest drafts - and gradually transformed the material of memory into fiction, thus endowing her work with artistic autonomy.

\section{Keywords}

Virginia Woolf, To the Lighthouse, genetic criticism, the creative process, draft 